rodzaju w Polsce), którego twórcą i kierownikiem (do 2005) był prof. Antoni Jackowski. Obecnie Zakładem kierują dr hab. Michał Paszkowski i dr Izabela Sołjan.

Izabela Soljan, dr (e-mail: i.soljan@geo.uj.edu. pl). Specjalność: geografia religii, geografia turyzmu. Zainteresowania badawcze: geografia religii; turystyka religijna; relacje środowisko-człowiekreligia, ze szczególnym uwzględnieniem migracji pielgrzymkowych; geografia religii Europy; geografia biblijna; przemiany krajobrazu sakralnego w Polsce.

Elżbieta Bilska-Wodecka, dr (e-mail: e.bilska@) geo.uj.edu.pl). Specjalność: geografia religii, geografia spoleczno-ekonomiczna. Zainteresowania badawcze: geografia religii, ze szczególnym uwzględnieniem migracji pielgrzymkowych; geneza, funkcjonowanie i typologia kalwaryjskich ośrodków kultu religijnego; rozmieszczenie religii na świecie.

Antoni Jackowski (e-mail: a.jackowski@geo.uj. edu.pl), prof. honorowy UJ, m.in. członek korespondent Papieskiej Międzynarodowej Akademii Maryjnej (Pontificia Academia Mariana Internationalis) w Rzymie, Society of Pilgrimages Studies (Allahabad, Indie). Specjalność: geografia religii, geografia turyzmu. Zainteresowania badawcze: geografia religii; turystyka religijna; geografia kultury, historia geografii i turystyki.

Od 1995 r. Zakład wydaje czasopismo naukowe „Peregrinus Cracoviensis”, jedyne tego typu w Europie. Pracownicy Zakładu opublikowali blisko 15 książek dotyczących badanej problematyki, m.in. podręczniki akademickie. Zakład Geografii Religii był organizatorem lub współorganizatorem wielu naukowych konferencji i seminariów.

\section{Antoni Jackowski}

\section{Geografia turyzmu w Uniwersytecie Wroclawskim Zakład Geografii Regionalnej i Turystyki}

Zainteresowanie problematyką geografii turyzmu w Instytucie Geografii i Rozwoju Regionalnego Uniwersytetu Wrocławskiego sięga pierwszych lat powojennych i wiąże się wówczas z pracami W. Walczaka, kierownika Zakładu Geografii Regionalnej. Należą do nich m.in. monografie-Ziemia Klodzka $(1951,1956)$ i Karkonosze (z T. Steciem, 1954), Turystyczna mapa Karkonoszy (1947) i Zarys geografii turystycznej Polski (1963). (its director until 2005). Currently the department is directed by $\mathrm{Dr}$ Michal Paszkowski (Doctor habilitatus) and Dr Izabela Sołjan.

Izabela Sołjan, PhD (e-mail: i.soljan@geo.uj. edu.pl). Specialisms: geography of religion and geography of tourism. Research interests: geography of religion, religious tourism, 'environment-man-religion' relations with emphasis on pilgrimages, the geography of religion in Europe, biblical geography, changes in Poland's sacred landscape.

Elżbieta Bilska-Wodecka, PhD (e-mail: e.bilska @geo.uj.edu.pl). Specialisms: geography of religion, socio-economic geography. Research interests: geography of religion with emphasis on pilgrimages; the origins, functioning and typology of centres of religious worship of the Calvary type; the distribution of religions in the world.

Antoni Jackowski (e-mail: a.jackowski @geo. uj.edu.pl), Honorary Professor at the Jagiellonian University and corresponding member of the Pontifical International Marian Academy (Pontificia Academia Mariana Internationalis) in Rome and the Society of Pilgrimage Studies (Allahabad, India). Specialies: geography of religion, graphy of religion, religious tourism, geography of culture, history of geography and tourism.

Since 1995 the department has published Peregrinus Cracoviensis, the only research journal of this type in Europe. The staff of the department have produced nearly 15 publications in book form on the subject, including academic textbooks. The Department of Geography of Religion has organised or co-organised many conferences and seminars.

Antoni Jackowski geography of tourism. Research interests: geo-

Interest in the problems of tourism geography in the Institute of Geography and Regional Development at the University of Wrocław dates back to the early post-war period and refers mostly to the work of W. Walczak, the head of the Regional Geography Department. The work includes monographs, The Ktodzko Region $(1951,1956)$, and The Karkonosze Mountains (with T. Steć, 1954), a Tourist map of the Karkonosze (1947), and an Outline of the Tourist Geography of Poland (1963). 
Od 1972 r. pod opieką merytoryczną Zakładu Geografii Regionalnej działa Podyplomowe Studium Geografii Turystycznej (obecna nazwa Podyplomowe Studium Turystyki i Edukacji Regionalnej), utworzone przez L. Baranieckiego i O. Rogalewskiego. Z inicjatywy J. Wyrzykowskiego, od 1987 r. Zaklad Geografii Regionalnej zmienił nazwę na Zakład Geografii Regionalnej i Turystyki oraz oferuje specjalność magisterską o tej samej nazwie. W przygotowaniu jest oferta drugiej specjalności - tourism, prowadzonej wyłącznie w języku angielskim.

Do tej pory we wrocławskim ośrodku geograficznym przeprowadzono trzy rozprawy habilitacyjne oraz 12 rozpraw doktorskich związanych $\mathrm{z}$ geografią turyzmu.

Do ważniejszych opracowań zespołowych w zakresie turystyki pod kierunkiem J. Wyrzykowskiego należą: ocena krajobrazu Polski w aspekcie fizjonomicznym na potrzeby turystyki (druga połowa lat 80., w ramach programu CPBP 08.06), koncepcja rozwoju turystyki w Sudetach i Karpatach (druga połowa lat 80., na zlecenie Głównego Komitetu Turystyki), ocena stanu i rozwoju turystyki $\mathrm{w}$ strefie przygranicznej $\mathrm{z}$ Niemcami (połowa lat 90.), studia nad uwarunkowaniami rozwoju turystyki zagranicznej w Europie Środkowej i Wschodniej (prace ciagke od 1990 r. w ramach międzynarodowego, nieformalnego zespołu badawczego), studia nad ruchem turystycznym przyjazdowym do Wrocławia (druga połowa lat 90., na zlecenie Urzędu Miejskiego we Wroclawiu), prace nad strategiami rozwoju turystyki na Dolnym Śląsku (od połowy lat 90.). Wyniki prac przedstawiono w kilku opracowaniach monograficznych i kilkudziesięciu artykułach. Do dorobku ośrodka wrocławskiego $\mathrm{w}$ zakresie geografii turyzmu zaliczyć należy również udział w opracowaniu podręcznika uniwersyteckiego pt. Geografia turystyki Polski (T. Lijewski, B. Mikułowski, J. Wyrzykowski, 1985, 1992, 1998, 2004), wyróżnionego nagrodą Ministra Edukacji Narodowej.

Od 1990 r., co dwa lata, Zakład Geografii Regionalnej i Turystyki organizuje międzynarodowe konferencje naukowe pt. „Uwarunkowania rozwoju turystyki zagranicznej w Europie Środkowej i Wschodniej" i wydaje zeszyty naukowe (w wersji angielskiej i polskiej) pod tym samym tytułem. Współpraca badawcza w tym zakresie, poza ośrodkami polskimi, dotyczy m.in. Uniwersytetów w Brnie, Lille, Lyonie, Lwowie, Mińsku, Monachium, Oradei, Pullman (USA), Wiedniu,
Starting from 1972 the Department of Regional Geography has had under its content-related supervision a Post-graduate Studium in Tourist Geography (currently called the Post-graduate Studium of Tourism and Regional Education) set up by L. Baraniecki and O. Rogalewski. On the initiative of Prof. Wyrzykowski the Department of Regional Geography has changed its name to the Department of Regional Geography and Tourism and has offered an MA specialization of the same name since 1987. A second specialization, Tourism, to be conducted solely in English is currently under preparation.

Since then the geographical centre in Wrockaw has supported three postdoctoral habilitation theses, (Rogalewski, 1972, Wyrzykowski, 1986, Iwicki, 2001) and twelve doctoral theses (Wyrzykowski, 1974. Gadzojanis, 1975, Wawrzyniak, 1975, Mikułowski, 1976, Nowak-Ferdhus, 1978, Werner, 1980, Klementowski, 1994, Potocki, 1997, Duda-Seifert, 2000, Widawski, 2000, Pstrocka, 2006, Migocka-Sendłak, 2007), all connected to the geography of tourism.

The most significant research on tourism carried out under the guidance of Prof. Wyrzykowski includes the estimation of Poland's landscape in the physiognomic aspect with relation to tourist needs (second part of ' 80 , in the CPBP 08.06 program), the concept for tourism development in the Sudety and Karpaty mountains (second part of '80, a commission from the General Tourism Committee), the estimation of the condition and development of tourism in the Polish - German borderland (mid '90), the study on the conditioning of foreign tourism development in Central and Eastern Europe (continuous work since 1990 as part of informal international research team), the study on Wroclaw's incoming tourist traffic (second part of '90, a commission of the Municipal Office of Wrocław, developing strategies for tourism development in Lower Silesia (since mid '90). The results have been presented in a number of monographs and numerous publications.

The work of the Wrockaw tourism geography centre also encompasses participation in writing a university textbook The Geography of Tourism in Poland' (T. Lijewski, B. Mikułowski, \& J. Wyrzykowski, editions in $1985,1992,1998,2004)$, which was granted a prize by the Ministry of Education.

Every second year since 1990 the Department of Regional Geography and Tourism has organized international conferences entitled The Conditions of Foreign Tourism Development in Central and Eastern Europe'. Their outcome is published as 'academic notes' (Zeszyty Naukowe) in Polish and in English under the same title. The department co-operates not only with other Polish 
Wilnie i Zagrzebiu. W ostatniej kadencji władz Międzynarodowej Unii Geograficznej J. Wyrzykowski jest stałym członkiem Komisji Geografii Turyzmu.

Jerzy Wyrzykowski

\section{Geografia turyzmu w Uniwersytecie Warszawskim Zakład Geografii Turyzmu i Rekreacji}

Początki geografii turyzmu na Uniwersytecie Warszawskim sięgają wczesnych lat 60 . W tym czasie Maria I. Mileska opublikowała wyniki swoich badań nad regionalizacją turystyczną Polski. Kolejnymi osobami - spośród geografów - które interesowały się turystyką i rekreacją byli Alicja Krzymowska-Kostrowicka i Michał Stalski. Zajmowali się oni - podobnie, jak wcześniej Mileska - planowaniem turystycznym i ekologia turystyczna. Pierwszy okres zakończył się mniej więcej pod koniec lat 70 .

W 1980 r. Alicja Krzymowska-Kostrowicka opublikowała książkę Terytorialny system rekracyjny. Analiza struktury i charakter powiqzań. Książka ta była rezultatem badań teoretycznych i praktycznych. Krzymowska-Kostrowicka byla pierwsza osobą w Polsce, która zastosowała w praktyce podejście systemowe $w$ geografii turyzmu. W następnej dekadzie prowadziła nadal tego rodzaju badania. W tym okresie powstały jej opracowania teoretyczne The system approach in modelling recreation (1984) i Tourist regions and erritorial recreational system (1986), a także wiele ekspertyz i wskazówek praktycznych dla planistów, administracji parków narodowych oraz władz lokalnych. W tym czasie głównym problemem w jej badaniach był wplyw bioklimatu i roślinności na turystykę i rekreację. Wyniki tych badań zostały opublikowane w $1992 \mathrm{r}$. w artykule Assessment of therapeutical values of natural environment for recreational needs. A case study of Warsaw environs. W roku 1997 Krzymowska-Kostrowicka wydała swoje główne dzieło w tej sferze jej zainteresowań - Geoekologia turystyki $i$ wypoczynku. W następnych latach książka ta wywarła wielki wpływ na innych geografów i specjalistów z zakresu nauk o środowisku zajmujących się turystyką i rekreacją.

W 1988 r. prof. A. Krzymowska-Kostrowicka zorganizowała na Wydziale Geografii i Studiów institutes but also with universities in Brno, Lille, Lyon, Lvov, Minsk, Munich, Oradea, Pullman (USA), Vienna, Vilnius and Zagreb. In the last term of office of the International Geographical Union Prof. Wyrzykowski is a permanent member of the Tourism Geography Committee.

Jerzy Wyrzykowski

\section{Geography of tourism at Warsaw University Department of the Geography of Tourism and Recreation}

The beginnings of tourism geography at Warsaw University date back to the early 1960s. At that time Maria Mileska published the results of her research on the tourist regionalisation of Poland. Other geographers who were interested in tourism and recreation were Alicja Krzymowska-Kostrowicka and Michał Stalski, and both of them, as Mileska before, were interested in tourism planning and tourism ecology. This initial period ran approximately until the end of the 1970s.

In 1980 Alicja Krzymowska-Kostrowicka published her book 'The spatial recreational system: an analysis of the structure and character of relations' (in Polish) resulting from both theoretical and practical studies. Krzymowska-Kostrowicka was the first in Poland to actually use a systems approach in tourism geography. In the next decade she continued similar studies publishing theoretical articles such as 'The systems approach in modelling recreation' (1984) and 'Tourism regions and the spatial recreational system' (1986), as well as giving many expert opinions and practical suggestions for planners, national park administrations, and local authorities. At that time the main topic of her research was the influence of bioclimate and vegetation on tourism and recreation. The results of these studies were published in 1992 in an article 'Assessment of the therapeutical value of the natural environment for recreational needs: the case study of the surroundings of Warsaw'. In 1997 Krzymowska-Kostrowicka published her major work in this field, i.e. The geoecology of tourism and recreation' (in Polish). In the years to follow this book has had a great impact on other geographers and environmentalists interested in tourism and recreation.

In 1988 Prof. Alicja Krzymowska-Kostrowicka organised a specialisation of tourism geo- 